\title{
Ripple effect, driving branch, and economic development: case of the agro-food industry in Côte d'Ivoire
}

\author{
Noufou Coulibaly ${ }^{*}$ (D) Siaka Kone ${ }^{1}$ (i) Gboko $_{\text {Kouamé }}$ Casimir $^{1}$ (D) \\ Kama Berte ${ }^{1}$ (D) Yapo Magloire Yapi ${ }^{2}$ (D)
}

${ }^{1}$ Management and Applied Economics Department, Institut National Polytechnique Houphouët Boigny, Yamoussoukro, Côte d'Ivoire. E-mail: noufou_coulibaly@yahoo.fr. "Corresponding author.

${ }^{2}$ Agriculture and Animal Science Department, Institut National Polytechnique Houphouët Boigny, Yamoussoukro, Côte d'Ivoire.

ABSTRACT: In Côte d'Ivoire, agricultural development has been made possible by the Government strategy to support it through an industrialization-based policy. However, the agricultural sector is still facing many difficulties, despite significant investment efforts undertaken to turn the country into a significant agricultural and agro-food industry (AFI) products exporter on the international market. This study evaluated the effectiveness of the driving role of AFI branches in the Ivorian economy.-We used Leontief's model, coupled with Diamond's model and Rasmussen's indices, to assess the ripple effects, and identify the driving branch in the Ivorian economy. Data used are derived from the InputOutput Table (IOT) of the 2018 National Accounts produced by the Government and aggregated into 21 branches or subsectors. Our study showed that there is no outstanding driving branch in the economy. However, some branches are close to compliance with driving branch status. For a driving sector to emerge, the Government should invest in priority order in the following branches: Grain Processing and Starchy Product Manufacturing (GPSPM), Cocoa \& Coffee Processing (CCP), Oilseed Industry (OI), Dairy Industry and Fruit \& Vegetable Industry (DIFVI), Beverage Industry (BI), Tobacco Industry (TI). And currently, the country's development strategy should be based primarily on these branches, because they are able to improve the effectiveness and efficiency of production system in the Agro-Food Industry (AFI) and, by extension, the economy. Key words: Côte d'Ivoire, investment planning, agricultural policy, ripple effect, driving branch.

Avaliação da eficácia dos efeitos puxadores da indústria agro-alimentar (IAA) na economia da Costa do Marfim

RESUMO: Na Costa do Marfim, o desenvolvimento agrícola tornou-se possível graças à estratégia de apoio do governo através de uma politica de industrialização. Contudo, o setor agrícola continua a enfrentar muitas dificuldades, apesar dos grandes esforços de investimento empreendidos para transformar o país num grande exportador de produtos agrícolas e de indústria agro-alimentar (IAA) no mercado internacional. O objetivo do presente estudo é avaliar a eficácia do papel motor dos ramos da Indústria Agro-alimentar (IAA) na economia da Costa do Marfim. Utilizámos o modelo de Leontief, juntamente com o modelo de Diamond e os indices de Rasmussen, para avaliar os efeitos puxadores e identificar o ramo motor da economia marfinense. Os dados utilizados provêm da Tabela Entradas-Saidas (TES) da Contabilidade Nacional de 2018, produzida pelo governo e que foi agregada em 21 ramos ou sub-sectores. Tendo em conta o princípio de identificação do ramo motor, os nossos resultados mostram que não existe verdadeiramente um ramo motor na economia marfinense. Entretanto, alguns ramos estão a aproximar-se desta conformidade de identificação de ramo motor. São, por ordem de conformidade no setor agro-alimentar: Trabalho de Grãos e Fabricação de Produtos à base de Amido (TGFPA); Transformação do Cacau e do Café (TCC); Indústria de Oleaginosas (IO); Indústria de Lacticinios e Indústria de Frutas e Legumes (ILIFL); Indústria de Bebidas (IB); Indústria do Tabaco (IT). Isso significa que, atualmente, a estratégia de desenvolvimento do país deverá apoiar-se, em primeiro lugar, nestes ramos, pois, são eles que podem melhorar a eficácia e a eficiência do sistema de produção da Indústria Agro-alimentar (IAA) e, portanto, a economia da Costa do Marfim.

Palavras-chave: Costa do Marfim, planejamento dos investimentos, política agrícola, efeitos puxadores, ramo motor.

\section{INTRODUCTION}

Côte d'Ivoire, a forest country in West Africa, has built its economic development on agriculture. This has been made possible by a policy of industrialization of the sector. According to RASTOIN (2012), DE BERNIS GERARD DESTANNE (1966), higher integrated branches of an economy are correlated with sustainable development achievement. Thus, where the branches in the agricultural sector and those in the Agro-Food Industry (AFI) are highly integrated, any innovation in one branch benefits the others. This has the advantage of increasing ripple effects, which in turn, have a positive impact on agricultural sector 
development (NOUFOU et al., 2019). This choice allowed the country to experience remarkable economic growth during its first two decades of independence. However, despite Government investment efforts, the agricultural sector still faces difficulties (low modernization, low yield, unachieved self-sufficiency and/or food security, significant post-harvest losses, low processing rate, poor marketing, high poverty, etc.), according to DUCROQUET et al., 2017. Additionally, over-indebtedness $(48 \%$ of GDP) has become unbearable for the economy (WORLD BANK, 2019). It is appropriate to look at the planning strategies, which can support the economy and enable sustainable development in the country.

The theoretical and empirical study of the structural changes that accompany development has revealed several universal trends. Some secular trends highlight the decline in the relative weight of agricultural sector in the economy. This relative decline is evidenced by the fall in agriculture's share of value added, employment, trade and consumption (DUCROQUET et al., 2017). Others argue that the development of AFI can help strike the right balance between agriculture and industry. HIRSCHMAN ALBERT (1968) linkage theory that the best development strategy is to select activities whose progress will stimulate further progress elsewhere, is in line with this second line of thought. The theory justifies assigning a significant role to AFI in development. According to this theory, any activity with significant interactions with the rest of the economy can be a powerful driver of economic growth. As AFI is supposed to have upstream (agricultural sector) and downstream (banking, insurance, trade, etc.) related to the rest of the economy, it seemed appropriate to wonder whether this sector is capable of driving development in the Ivorian economic model. In other words, can AFI be considered as an industrializing industry?

This study identified the Agro-Food Industry's driving branches; ie, branches which are both powerful and sensitive, with homogeneous degrees of impact on the other branches; in order to prioritize investments in these branches, for an efficient Ivorian economy.

The first section of the manuscript covers Literature Review, the second focuses on the Methodology, and the third and final section covers the Results and Discussion.

\section{LITERATURE REVIEW}

\section{Agro-food industry}

The AFI sector is the set of industries that process plant- or animal-based raw materials into products intended for human or animal consumption (BERNADE \& LECLERCQ, 2005). Under the Ivorian classification of activities and products, this sector is composed of eight (8) branches: Meat and Fish Production (MFP); Grain Processing and Starchy Product Manufacturing (GPSPM); Cocoa \& Coffee Processing (CCP); Oilseed Industry (OI); Bakery, Pastry and Pasta (BPP); Dairy Industry and Fruit \& Vegetable Industry (DIFVI); Beverage Industry (BI), and Tobacco Industry (TI).

Many studies tend to show that AFI is the industrial sector that offers the greatest opportunities in terms of sustainable growth, employment and poverty reduction in Africa. The strategic role of agro-food activities in development can be explained by several factors. Technology and innovation are essential for economic development, and AFI has traditionally been the primary source of innovation in modern economy (GAULT \& ZHANG, 2010). Research and Development activities of agro-food companies have been key to technological advances in the global economy (SHEN et al., 2007). The agro-food sector is an essential source of demand for other sectors, since agro-food companies are particularly heavy consumers of banking, transport, insurance and communication services. Also, agro-food sector boosts the growth of the agricultural sector by creating demand. The sector; therefore, has significant downstream and upstream ripple effects and thus contributes to domestic investment, employment and production for development purposes. The agro-food sector is also attractive because according to Engel's law, as per capita income rises, the share of agriculture in total household expenditure declines and the share of processed products increases. As a result, agro-food products offer significant opportunities for export expansion and are; therefore, a key driver of growth in merchandise trade (CNUCED, 2018).

AFI still plays a minor role in the Ivorian economy in terms of value and contribution to growth. It accounts for $21.4 \%$ of GDP in the secondary sector, and 6\% of the Ivorian GDP in 2017 with an annual growth of $2 \%$ over the last 5 years, well below the overall growth of $9 \%$ over the same period. The employment rate offered by the sector is less than $7 \%$ of the population. The sector's growth is driven by the cocoa and cashew nut processing industries and by increased private investment. From 2013 to 2017 , there was a $32 \%$ increase in export value for shelled cashew nuts and $8 \%$ for cocoa products. Apart from oil palm (100\%) and seed cotton (100\%), the processing rates of food production and exports remain very low, depriving the country of a large share 
of value added (AFRICAN DEVELOPMENT BANK, 2018; WORLD BANK, 2019).

Côte d'Ivoire, the leading producer of cocoa beans, processes only $32 \%$ of its production locally and less than $5 \%$ of other exports such as cashew nuts, coffee, rubber, mango and pineapple. The products of the Ivorian Agro-Food Industry are essentially low-processing products, i.e. products of $1^{\text {st }}$ or $2^{\text {nd }}$ stage processing such as cocoa paste, cocoa butter, cocoa powder, crude palm oil, palm kernel oil, coconut oil, etc. (MINISTRY OF INDUSTRY $\&$ MINES, 2017). The processing of agricultural products is thus a very important stage and justifies interest in identifying the driving branch of the production system of the economy.

\section{Production system and Leontief's model}

Production System is a term mainly used to understand what farmers do, how they combine several agricultural activities and practices on their farms, what is the rationality of their practices, what the technical and economic constraints are and to assess the technical performance and economic results (HUBERT \& SOPHIE, 2006). Industrial Production System can; therefore, be defined as the combination of production factors by industrial units to create wealth. In view of the positive effects that can be induced by AgroFood Industry as illustrated above, we believed it is appropriate to analyse whether the industrial production system has one or more driving branches.

Leontief's model is a tool for analysing the performance of an agro-food production system (AFS) by assessing ripple effects (KARANGWA \& DECALUWE, 1983). Specifically, Leontief's model is a tool for analysing the intersectoral trade flows of an economy. It can be used to:

1) Identify the branch or sector that drives an economy, i.e. the branch or sector that is capable of driving growth in the economy (Upstream Ripple Effect or Power) and in turn being sensitive to the impetus of the same economy (Downstream Ripple Effect or Sensitivity); and

2) Identify which one of domestic or foreign market best drives economic growth. This model uses data from the Input-Output Table (IOT), also called flow table, or Supply Use Table (SUT) provided by national accounts (NOUFOU et al., 2019). LEONTIEF (1936) is the forerunner of the input-output table, commonly known as IOT. The analysis of the IOT is based on a system of linear equations showing the distribution of an industry's output across the economy (YU et al., 2010). IOT is a double-entry table that tracks all economic transactions in goods and services. It describes the structure of the national economy and the structure of product flows, which makes it useful for prioritizing activities and highlighting the driving and driven branches of the economy. It is considered not only as a tool for predicting the effect of a given policy on the output of branches, but also as a tool for economic impact analysis, as it measures the effects of the change an item of final demand for a strategic product on the entire economy (ZAOUJAL, 2016). Leontief's model helps assess the ripple effects of branches of the economy.

The concept of ripple effect derives from the growth pole theory expounded by PERROUX (1973). This theory was developed to understand and explain underdevelopment based on the effects of the relationship between two unequally developed spaces (MYRDAL, 1959). Said theory was taken up by many authors including DE BERNIS BERNARD DESTANNE (1966), who took up this idea under the name of "industrialising industries". The notion of growth pole is linked to the idea of functional relations between different sectors in an economy, leading to the notion of Driving Industry. HIRSCHMAN (1968) helped to move from the theory of growth poles to the "Upstream and Downstream principle between branches". For Hirschman, an investment in an industrial sector gives rise to upstream or downstream ripple effects. The establishment of driving industries in an enabling space accelerates development (COURLET, 1988). Given the above, we can say that a sound knowledge of relations established between all the branches of an economy is a means of making efficient investment. According NOUFOU \& GÉRARD, (1993), ripple effects are defined as actions whereby an increase in the growth rate of output (or productivity) of an activity A leads to an increase in the growth rate of profit (or productivity) of an activity $\mathrm{B}$. The driving unit $\mathrm{A}$ acts on the unit $\mathrm{B}$ through a set of dimensional effects. That is, unit A leads to additional production of $B$ by the size of the purchases made from $\mathrm{B}$. The driving branch is the branch of the economy which is both the most powerful (highest upstream ripple effect) and the most sensitive (highest downstream ripple effect).

Based on the knowledge of ripple effects, the methodology for this study is developed and illustrated as below.

\section{HYPOTHESIS AND METHODOLOGY}

\section{Hypothesis}

The hypotheses to be tested in order to verify whether Agro-Food Industry is still the driving 
sector of the Ivorian economy, are worded as follows:

H1: Agro-Food Industry (AFI) is the driving sector of the Ivorian economy.

$\mathrm{H} 2$ : Agro-Food Industry is not a driving branch/sector of the Ivorian economy.

\section{Methodology}

Approach

This study will be conducted in two stages:

Assessing the upstream and downstream ripple effects of branches or sectors of the economy;

Identifying the driving branch or sector of the economy.

\section{Tools}

In this section, the four key methodological dimensions of the input-output model that led us to select this model are discussed. These are:

- An analytical dimension, whereby the model is both an interpretation of the theory and a tool for interpreting data. Like any model, Leontief's is a simplification of reality and an interpretation of the theory itself. Input-output analysis is an economic modelling using the input-output table (IOT) to forecast the influence of changes in a particular sector of activity or changes in consumption on the rest of the economy. It provides a coherent representation of national production.

- A statistical dimension, since the variables and parameters of the model are evaluated not by econometric estimation methods, but by what Leontief calls "direct structural analysis": rather than a testable model, as found in econometrics. Leontief builds an empirically significant model.

- A calculative dimension, because the mathematical model is developed in close relation with the technical means of calculation to form a calculable model. We considered Leontief's model as a particular case of the general equilibrium theory, as its model overcome the contradictions of prices and quantities equilibrium analysis in partial equilibrium.

IOTs were conceived as an accounting matrix twinned with a mathematical model of general economic equilibrium. The scheme was designed as an alternative to econometrics, as Leontief considered the latter ill-equipped to link economic theory with statistical measurement. We chose Leontief's model because of its robustness in assessing ripple effects. This allowed us to identify the driving branches/ subsectors of an economy based on the assessment of upstream and downstream effects.

- The limits of the model: Leontief's model does not provide an explanation of changes and evolutions and gives an essentially static image. The model ignored technical progress, changes in behaviour, everything that constitutes structural change. Such a model is acceptable only for small variations and for a short term. To this are added other parameters, such as not taking into account in the IOT, such as climatic hazards, training and production technologies. These are the limits of this model. And since structural changes are weak and slow in Africa, then the model remains well suited to the economies of undeveloped countries like Côte d'Ivoire.

a) Ripple effects assessment

Equation 1 below is a mathematical translation of the input-output table from the national accounts. Equations 2 to 8 translate the Leontief model from the input-output table (IOT). And equations 9 to 13 are an improvement of the Leontief model by Diamond and Rasmussen in the identification of a driving branch/subsector for effective investment planning. According to LEONTIEF (1936), as taken over by NOUFOU et al., (1993, 2019), in the theory of Leontief's model, the total output of a branch/sector is equal to the sum of intermediate uses and final consumption of products which is a mathematical transcription of Governmentproduced national accounts, as illustrated by the mathematical equation below:

$\mathrm{Xij}+\mathrm{Yi}=\mathrm{X}_{\mathrm{J}}$

Where $\mathrm{Xij}$ represents the purchases of sector $\mathrm{j}$ from sector $\mathrm{i}$; $\mathrm{Yj}$ the final demand for goods of sector $\mathrm{j}$; $\mathrm{Xj}$ the total gross output of the sector. Technical coefficients aij are determined as follows:

$$
a i j=\frac{X i j}{X j}
$$

Hence $X \mathrm{ij}=\mathrm{aij}^{*} \mathrm{Xj}$

Equation (1) can be rewritten as

$\sum \mathrm{aij}^{*} \mathrm{Xj}+\mathrm{Yj}=\mathrm{Xj}$

For an economy with n sectors, coefficients aij form a matrix called $A$. A simplified form of the system of equations representing the economy leads to the following equation:

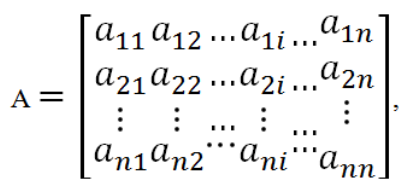

This matrixis commonly referred to as the technical coefficient matrix. In Leontief's model, aij is assumed to be fixed and stable because technical production are complementary factor, returns to scale are constant and the model is short term; stable because it is not significantly affected by technological change. So we can have: 
$\mathrm{X}=\mathrm{AX}+\mathrm{Y}$

An arrangement of equation (6) gives:

$\mathrm{X}=(\mathrm{I}-\mathrm{A})-1^{*} \mathrm{Y}$

(6)

Where the matrix (I-A) $)^{-1}=\left[\begin{array}{cccccc}b_{11} & b_{12} & \ldots & b_{1 i} & \ldots & b_{1 n} \\ b_{21} & b_{22} & \ldots & b_{2 i} & \ldots & b_{2 n} \\ \vdots & \vdots & & \vdots & & \vdots \\ b_{11} & \ldots & b_{2} & \ldots & b_{i i} & b_{i n} \\ \vdots & \vdots & \vdots & \vdots & \vdots \\ b_{n 1} & b_{n 2} & b_{n i} & b_{n n}\end{array}\right]$ (8)

According to LEONTIEF (1953), the sum of technical coefficients bij of this matrix per column is the upstream ripple effect $\left(\mathrm{C} \sum \mathrm{bij}\right)$, and is called the power of the branch. The sum of technical coefficients per line is the measurement of the downstream ripple effect (L $\sum$ bij). This is called industry sensitivity.

The Diamond's method allowed to associate a socio-economic objective in the Leontief model. We chose value added as socio-economic parameter because the more a branch or sector improves its value added, the more it improves the performance of the economy in order to reduce poverty, unemployment etc. This yields a new matrix called " $P$ ":

$\mathrm{P}=\mathrm{D}^{*}(\mathrm{I}-\mathrm{A})^{-1}$

Where $\mathrm{D}$ is the diagonal matrix of socioeconomic objective coefficients (DIAMOND, 1976; NOUFOU COULIBALY \& GÉRARD GHERSI, 1993). We used the increase in value added (VA), which is expressed as an industry's value added over the total value added of the economy, in the national account.

b) Identifying the driving branch or sector of the economy

We will use the Rasmussen Index as a tool to identify the driving sector or the driving branch. Although, it does not call into question the quality of the measurement of ripple effects of the sectors of an economy recognised in the matrix $\mathrm{P}=\mathrm{D}^{*}(\mathrm{I}-\mathrm{A})-1$, this matrix $\mathrm{P}$ is also criticised for not taking into account the relative weight of the various branches of the economy and the degree of influence that a branch may have on the various branches of the economy, both upstream and downstream. In order to address this limitation, the Rasmussen Indexes are applied to it. The formulae for calculating the upstream (Ej) and downstream (Ei) ripple effects, and their degrees of impact variation - $\mathrm{Vj}$ and $\mathrm{Vi}$ respectively - are presented below:

$$
\begin{aligned}
\mathrm{Ei} & =\frac{(1 / m) L \sum b i j}{\left(\frac{1}{m^{2}}\right)\left(C \sum b i j+L \sum b i j\right)} \\
\mathrm{Ej} & =\frac{(1 / m) C \sum b i j}{\left(\frac{1}{m^{2}}\right)\left(C \sum b i j+L \sum b i j\right)}
\end{aligned}
$$

$\mathrm{Vi}=\frac{\sqrt{(1 / m-1)\left[\sum\left(b i j-1 / m \times C \sum b i j\right)\right]^{2}}}{(1 / m) C \sum b i j}$

$\mathrm{Vj}=\frac{\sqrt{(1 / m-1)\left[\sum\left(b i j-1 / m \times L \sum b i j\right)\right]^{2}}}{(1 / m) L \sum b i j}$

Where:

$\mathrm{m}$ : number of branches or sectors;

$\mathrm{C} \sum \mathrm{b}_{\mathrm{ij}}$ and $\mathrm{L} \sum \mathrm{b}_{\mathrm{ij}}$ : the sum of technical coefficients bij of this matrix per column (upstream ripple effect), per line (downstream ripple effect);

$E_{j}$ : relative weight of the upstream ripple effects of branch $\mathrm{j}$ in the economy compared to the relative weight of the upstream and downstream ripple effects of branch $\mathrm{j}$ in the economy. Ej is called the Dispersion Power Index.

$E_{i}$ : relative weight of ripple effects downstream of branch $\mathrm{i}$ in the economy compared to the relative weight of ripple effects upstream and downstream of the said branch in the economy. Ei is the Dispersion sensitivity index.

$\mathrm{V}_{\mathrm{j}}$ : shows the degree of variation in the upstream ripple effects of branch $j$ on the other branches of the economy. The smaller this degree of variation, the more the branch impacts the other branches to homogeneous degrees. This is what is sought. It is also called: Degree of variation of Dispersion Power Index.

$\mathrm{V}_{\mathrm{i}}$ : shows the degree of variation in ripple effects downstream of branch $\mathrm{i}$ on other branches of the economy. The smaller this degree of variation, the more the branch impacts the other branches to homogeneous degrees. This is what is sought. It is also called: Degree of variation of Dispersion sensitivity Index.

According to RASMUSSEN (1956) again, the lower the $\mathrm{V}_{\mathrm{j}}$ and $\mathrm{V}_{\mathrm{i}}$, the more homogeneous the upstream and downstream ripple effects tend to be. A branch is a driving branch if $E_{j}$ and $E_{i}$ are high and if at the same time $\mathrm{V}_{\mathrm{j}}$ and $\mathrm{V}_{\mathrm{i}}$ are relatively low (DIAMOND, 1976 cited by NOUFOU \& GÉRARD, 1993). In the interest of ranking the branches, the four (4) estimated variables $\left(V_{i}, V_{i}, E_{j}\right.$, and $\left.V_{i}\right)$ are assigned a score on a 20 -point scale.

\section{Study area and nature of data}

The study takes place in Côte d'Ivoire. The data used in it are secondary quantitative data from the latest National Accounts (2018) produced by the National INSTITUTE OF STATISTICS OF CÔTE D'IVOIRE (2020) every three years. The Ivorian IOT is divided into 44 branches, who have been aggregated into 21 subsectors or branches in 
order to study the driving branch as policies are drawn up by sector/subsector for more efficiency. The branches are:

1- Food Agriculture (FA), 2-Industrial or Export Agriculture (IEA); 3- Livestock and Hunting (LH); 4- Fisheries (F); 5-Meat and Fish Production (MFP); 6-Grain Processing and Starchy Product Manufacturing (GPSPM); 7-Cocoa and Coffee Processing (CCP); 8-Oilseed Industry (OI); 9 Bakery, Pastry and Pasta (BPP); 10-Dairy Industry and Fruit \& Vegetable Industry (DIFVI); 11-Beverage Industry (BI); 12-Tobacco Industry (TI); 13Wood Industry (WI); 14-Chemical Industry (CI); 15-Construction and Public Works (CPW); 16-Energy and Water (EW); 17-Miscellaneous Industries (MI); 18-Oil Extraction/Mining and Refining Industry (OEMRI); 19-Public Services (PuS); 20- Private Services (PrS); 21-Other Branches (OBs).

The two key sectors of the Ivorian economy are: Agriculture (Branches 1 to 4), and Agro-Food Industry (Branches 5 to 12).

\section{RESULTS AND DISCUSSIONS}

\section{Descriptive statistics of the input-output table (IOT)} used in this study

The agricultural and agro-industrial sector continues to occupy a preponderant place in the Ivorian economy with a contribution in 2018 estimated at $26 \%$ of GDP, including $6.30 \%$ for the agro-food industry, and $11 \%$ for Food Agriculture. The agricultural and agro-industrial sector accounts for $40 \%$ of export earnings. It employs $66 \%$ of the country's active population, including a high proportion of women (54.3\%). It is one of the pillars of economic growth in particular, thanks to the coffee and cocoa. The Ivorian agricultural sector as a whole experienced remarkable growth during the first twenty years of independence was characterized by results that propelled the country among the world's largest producers of tropical agricultural raw materials. In terms of production, the country is: $1^{\text {st }}$ in the world for cocoa, $15^{\text {th }}$ in the world for coffee, $7^{\text {th }}$ in the world for rubber, $11^{\text {th }}$ in the world for oil palm and $1^{\text {st }}$ in the world for cashew nuts. As such, the country must, and for a long time, continue to rely on the agricultural sector to give itself the chance to promote the massive creation of young jobs, capable of ensuring not only the empowerment of young people, but also their contribution to the modernization and transformation of the agricultural sector, for its sustainable development. The following section discusses the analysis of ripple effects.

\section{Ripple effects assessment}

Ripple effects for the aggregated 21 branches of the economy using the Leontief model are compiled in table 1 .

\section{Upstream ripple effect with Leontief model}

Upstream ripple effect is used to measure the propensity of a branch to boost the economy, also called branch power. A detailed study of branches of the Agro-Food Industry (AFI) shows that the $1^{\text {st }}$ rank of Agro-Food Industry in terms of upstream ripple effect is mainly due to the Bakery-Pastry-Pasta (2.96\%), Meat \& Fish (2.93\%), Oilseed Industry (2.55\%), Cocoa \& Coffee Processing (2.13\%) branches (Table 1). The Bakery-Pastry \& Pasta (BPP) industry is most stimulating in the AFI and the economy. One percent increase in the BPP subsector, allows the economy to produce $2.96 \%$ units. This is well justified by the fact that the Bakery-Pastry \& Pasta industries are mostly $2^{\text {nd }}$ and $3^{\text {rd }}$ processing industries. As a result, they use the output from Grain Processing and Starchy Product Manufacturing (2.06\%), Coffee \& Cocoa Processing (2.14\%), Oilseed Industry, Other branches, and their own output to produce their goods. Therefore, a demand for one product unit from this subsector also leads to a demand for several other subsectors. This also applies to the Meat \& Fish branch, which uses output from Food Agriculture; Livestock and Hunting; Fisheries; Oilseed Industry; Dairy Industry and Fruit \& Vegetable Industry; Other Branches; and part of its own output. In short, the more a subsector uses output from others in significant quantities, the more it has the capacity to boost the economy.

The Bakery-Pastry \& Pasta (BPP) subsector is modernizing, and is expanding very fast in the country. The rise of this branch has a social and economic implication - increased import of wheat from the international market (France), and food dependence. However, the possibility of substituting up to $15 \%$ of wheat with local products such as cassava, soybeans and sweet potato flour will undoubtedly help develop these crops.

\section{Downstream ripple effect with Leontief model}

The downstream ripple effect shows how well the economy is able to boost a branch or subsector. This is called branch/subsector sensitivity. The most sensitive subsector of the economy is the Private Service branch (PrS), with a downstream ripple effect of $4.82 \%$. This means that when the economy increases by $1 \%$ unit, it allows the "Private Service" (PrS) branch to produce $4.82 \%$ units. This high sensitivity of the Private Service (PrS) branch results from its 
Table 1 - The upstream and downstream ripple effects of the economy's branches with Leontief method.

\begin{tabular}{|c|c|c|}
\hline $\begin{array}{l}\text { Ripple Effects } \\
\text { Branches or subsectors of the economy }\end{array}$ & $\begin{array}{c}\text { Upstream } \\
\text { Ripple Effect (\%) }\end{array}$ & $\begin{array}{c}\text { Downstream Ripple } \\
\text { Effect (\%) }\end{array}$ \\
\hline Food Agriculture (FA) & 1.287 & 2.387 \\
\hline Industrial or Export Agriculture (IEA) & 1.548 & 2.505 \\
\hline Livestock and Hunting (LH) & 1.699 & 1.291 \\
\hline Fisheries $(\mathrm{F})$ & 2.507 & 1.304 \\
\hline Meat and Fish Production (MFP) & 2.934 & 1.172 \\
\hline Grain Processing and Starchy Product Manufacturing (GPSPM) & 2.063 & 1.575 \\
\hline Cocoa and Coffee Processing (CCP) & 2.136 & 1.089 \\
\hline Oilseed Industry (OI) & 2.551 & 2.314 \\
\hline Bakery, Pastry and Pasta (BPP) & 2.964 & 1.002 \\
\hline Dairy Industry and Fruit \& Vegetable Industry (DIFVI) & 1.790 & 1.377 \\
\hline Beverage Industry (BI) & 1.746 & 1.271 \\
\hline Tobacco Industry (TI) & 2.202 & 1.000 \\
\hline Wood Industry (WI) & 2.334 & 1.968 \\
\hline Chemical Industry (CI) & 2.285 & 3.730 \\
\hline Construction \& Public Works (CPW) & 1.510 & 1.498 \\
\hline Energy \& Water (EW) & 2.489 & 1.678 \\
\hline Miscellaneous Industries (MIs) & 2.090 & 2.058 \\
\hline Oil Extraction/Mining and Refining & 1.459 & 4.130 \\
\hline Public Services (PuS) & 1.432 & 1.000 \\
\hline Private Services (PrS) & 1.639 & 4.820 \\
\hline Other Branches (OBs) & 1.722 & 3.213 \\
\hline
\end{tabular}

strong incorporation of new technological innovations thanks to globalization (Cell phone, internet, networks etc.). For AFIs, the most sensitive subsector is the Oilseed Industry (2.31\%). It has a mixed commercial orientation, i.e. its production is marketed both in the domestic and international markets. As the domestic market is growing, the industry uses any innovations to reach its target.

\section{Upstream and downstream ripple effect with diamond method}

For a more stringent measurement of ripple effects, we integrated the Diamond method into Leontief's method. The new measurement is compiled in table 2. The Diamond matrix helped adjust the results obtained with Leontief by reflecting the socio $\neg$ economic dimension (value added). It appears from table 2 that the upstream and downstream ripple effects are weaker when value added (VA) is used as an adjustment parameter. These results reflected the fact that the branches of the economy produce less value added, resulting in poor performing of national economy. The most powerful subsector of the economy is the Private Services branch $(0.251 \%)$, followed in descending order by Other Branches (0.221\%),
Public Services (0.174\%), Chemical Industry (0.152\%), and Industrial \& Export Agriculture $(0.150 \%)$. These results also reflect the fact that the most sensitive sector, according to the Leontief model, has become the most powerful, meaning that the private sector has increased vitality, with an average growth rate of $7.3 \%$ per year, according to the WORLD BANK (2019).

The most powerful subsector of the AFIs is the Coffee \& Cocoa Processing branch $(0.129 \%)$, followed by the Meat and Fish subsector $(0.123 \%)$. In Agro-Food Industries, the Coffee \& Cocoa Processing (CCP) subsector would rank $10^{\text {th }}$, and Meat \& Fish Production (MFP) would rank $12^{\text {th }}$. This means that Agro-Food Industries (AFI) are not powerful when the contribution of subsectors to value added creation is factored in. They are less powerful than Agriculture subsectors (IEA, FA and FFF), except for the Livestock \& Hunting (LH). AgroFood Industry, taking into account the value added, has become less vibrant and been relegated to the $10^{\text {th }}$ rank of powerful sectors.

\section{Identification of the driving subsector/sector of the economy}

To identify the actual driving subsector incorporating socio-economic factors, we calculated 
Table 2 - The upstream and downstream ripple effects of the economy's branches with Diamond method.

\begin{tabular}{|c|c|c|}
\hline $\begin{array}{l}\text { Variables } \\
\text { Branches of the economy }\end{array}$ & Upstream Ripple Effect (\%) & Downstream Ripple Effect (\%) \\
\hline Food Agriculture (FA) & 0.147 & 0.277 \\
\hline Industrial or Export Agriculture (IEA) & 0.150 & 0.254 \\
\hline Livestock and Hunting (LH) & 0.056 & 0.013 \\
\hline Fishing and Fish Farming (FFF) & 0.130 & 0.001 \\
\hline Meat and Fish Production (MFP) & 0.123 & 0.003 \\
\hline Grain Processing and Starchy Product Manufacturing (GPSPM) & 0.120 & 0.008 \\
\hline Cocoa and Coffee Processing (CCP) & 0.130 & 0.027 \\
\hline Oilseed Industry (OI) & 0.112 & 0.045 \\
\hline Bakery, Pastry and Pasta (BPP) & 0.114 & 0.001 \\
\hline Dairy Industry and Fruit \& Vegetable Industry (DIFVI) & 0.069 & 0.020 \\
\hline Beverage Industry (BI) & 0.057 & 0.012 \\
\hline Tobacco Industry (TI) & 0.115 & 0.002 \\
\hline Wood Industry (WI) & 0.145 & 0.031 \\
\hline Chemical Industry (CI) & 0.152 & 0.174 \\
\hline Construction \& Public Works (CPW) & 0.137 & 0.129 \\
\hline Energy \& Water (EW) & 0.134 & 0.012 \\
\hline Miscellaneous Industries (MIs) & 0.111 & 0.052 \\
\hline Oil Extraction/Mining and Refining & 0.124 & 0.305 \\
\hline Public Services (PuS) & 0.174 & 0.127 \\
\hline Private Services (PrS) & 0.251 & 0.855 \\
\hline Other Branches (OBs) & 0.222 & 0.425 \\
\hline
\end{tabular}

the Rasmussen index, which takes into account the weight of each branch in the economy and the variation in the level of impact of a subsector on other subsectors in the economy. The calculation of this index from equation 10 to 13 is compiled in table 3 below.

\section{Dispersion power and dispersion sensitivity index}

Table 3 shows that the branches of AFI have become powerful and moderately sensitive. The dispersion power index of the Coffee \& Cocoa Processing branch (13.92) means that the economy produces an income of $13.92 \%$ units for a demand of $1 \%$ unit for the Coffee \& Cocoa Processing branch. Its dispersion sensitivity index is estimated at $7.08 \%$. This means that for an overall demand of $1 \%$ unit of goods in the economy, the Coffee \& Cocoa Processing branch produces $7.08 \%$ of income units. In terms of the degree of variability of sensitivity and power, the smaller the sensitivity and power, the more robust the index. For the Agriculture sector, the most powerful sector in terms of income is the Livestock \& Hunting branch $(10.99 \%)$. For a unit demand, it provides an income of $10.99 \%$ units to the economy against $7.27 \%$ for Industrial \& Export Agriculture, and $7.05 \%$ for Food Agriculture. Likewise, for Agriculture, the most sensitive branch is Food Agriculture (13.95\%). In the AFI, the best performing branch in terms of power is the Bakery, Pastry \& Pasta subsector (15.64\%), followed by the Meat and Fish branch (14.98\%). This performance from the Bakery, Pastry \& Pasta subsector is because it absorbs up to $43 \%$ of the production by the Grain Processing and Starchy Products branch absorbs the production from several other branches in smaller proportions. The most sensitive of the AFIs is the Oilseed Industry (9.59\%). In fact, it has the capacity to be more positively driven by the favourable economic situation of the Ivorian economy. In the entire economy, the Bakery, Pastry \& Pasta subsector is the strongest in terms of power; the Public Services (PuS) subsector ranks first in terms of sensitivity, followed by the Private Services (PrS) subsector and Other Branches (OBs). However, these branches have high degrees of power variability and sensitivity.

\section{The driving branch or subsector}

Taking into account the driving subsector identification principle whereby a subsector is said to be a driving subsector if $\mathrm{Ej}$ and Ei are high and at the same time if $\mathrm{Vj}$ and $\mathrm{Vi}$ are relatively low (DIAMOND, 
Table 3 - The upstream and downstream ripple effects of the economy's branches and its degree of variation with Rasmussen method.

\begin{tabular}{|c|c|c|c|c|}
\hline \multirow[t]{2}{*}{ Ripple Effects Branches of the economy } & $\begin{array}{l}\text { Dispersion Power } \\
\text { Index } \\
\text { (Upstream Ripple } \\
\text { Effect) }\end{array}$ & $\begin{array}{c}\text { Dispersion } \\
\text { Sensitivity Index } \\
\text { (Downstream } \\
\text { Ripple Effect) }\end{array}$ & $\begin{array}{c}\text { Degree of } \\
\text { variation of } \\
\text { Dispersion Power } \\
\text { Index }\end{array}$ & \multirow{2}{*}{$\begin{array}{c}\text { Degree of variation } \\
\text { of Dispersion } \\
\text { Sensitivity Index } \\
V_{\mathrm{i}}(\%)\end{array}$} \\
\hline & $E_{j}(\%)$ & $\mathrm{E}_{\mathrm{i}}(\%)$ & $\mathrm{V}_{\mathrm{j}}(\%)$ & \\
\hline Food Agriculture (FA) & 7.055 & 13.945 & 1.736 & 1.666 \\
\hline Industrial or Export Agriculture (IEA) & 7.270 & 13.730 & 2.233 & 2.257 \\
\hline Livestock and Hunting (LH) & 10.997 & 10.003 & 1.332 & 2.309 \\
\hline Fisheries $(\mathrm{F})$ & 13.717 & 7.283 & 2.297 & 1.302 \\
\hline Meat and Fish Production (MFP) & 14.985 & 6.015 & 4.064 & 1.361 \\
\hline $\begin{array}{l}\text { Grain Processing and Starchy Product } \\
\text { Manufacturing (GPSPM) }\end{array}$ & 12.227 & 8.773 & 0.019 & 1.043 \\
\hline Cocoa and Coffee Processing (CCP) & 13.917 & 7.083 & 0.589 & 1.979 \\
\hline Oilseed Industry (OI) & 11.411 & 9.589 & 1.360 & 0.381 \\
\hline Bakery. Pastry and Pasta (BPP) & 15.644 & 5.356 & 4.709 & 1.619 \\
\hline $\begin{array}{l}\text { Dairy Industry and Fruit \& Vegetable } \\
\text { Industry (DIFVI) }\end{array}$ & 11.830 & 9.170 & 0.784 & 1.684 \\
\hline Beverage Industry (BI) & 12.414 & 8.586 & 0.949 & 2.104 \\
\hline Tobacco Industry (TI) & 14.780 & 6.220 & 1.337 & 1.996 \\
\hline Wood Industry (WI) & 11.545 & 9.455 & 1.559 & 0.180 \\
\hline Chemical Industry (CI) & 7.831 & 13.169 & 0.383 & 3.832 \\
\hline Construction \& Public Works (CPW) & 10.623 & 10.377 & 1.551 & 1.528 \\
\hline Energy \& Water (EW) & 10.844 & 10.156 & 1.783 & 0.912 \\
\hline Miscellaneous Industries (MIs) & 10.790 & 10.210 & 0.331 & 0.316 \\
\hline Oil Extraction/Mining and Refining & 6.922 & 14.078 & 0.589 & 3.463 \\
\hline Public Services (PuS) & 4.868 & 16.132 & 7.211 & 3.091 \\
\hline Private Services (PrS) & 5.150 & 15.850 & 0.768 & 8.737 \\
\hline Other Branches (OBs) & 7.209 & 13.791 & 0.139 & 3.393 \\
\hline
\end{tabular}

1976 cited by NOUFOU \& GÉRARD, 1993). To rank the subsectors, the four (4) estimated variables ( $\mathrm{Vj}, \mathrm{Vi}$, $\mathrm{Ej}$, and $\mathrm{Vi}$ ) are assigned a score on a 20-point scale. The subsector with the highest sum of scores will be ranked highest. Our results showed that there is not really a driving subsector in the Ivorian economy, and confirm Hypothesis 2 that the "Agro-Food Industry is not the driving sector of the Ivorian economy". Our results confirmed Koko study (2013). However, some subsectors are close to compliance with driving subsector status, with high scores. These are, in order of compliance:

$-1^{\text {st: }}$ : Miscellaneous Industries (MIs);

$-2^{\text {nd: }}$ Grain Processing and Starchy Product Manufacturing (GPSPM);

$-3^{\text {rd: }}$. Wood Industry (WI);

$-4^{\text {th }}$ : Cocoa \& Coffee Processing $(\mathrm{CCP})$;

$-5^{\text {th}}$ : Oilseed Industry (OI);

$-6^{\text {th }}$ : Dairy Industry and Fruit \& Vegetable Industry (DIFVI); and Other Branches (OBs); $-8^{\text {th }}$ : Building Materials; and Energy \& Water (EW); $-10^{\text {th: }}$ Beverage Industry (BI),

$-11^{\text {th: }}$ Tobacco Industry (TI); Food Agriculture (FA); Fishing \& Fish Farming (FFF); Oil Extraction/Mining and Refining.

Classification of the ability of branches to become driving branch

The Ivorian Agro-Food Industries (AFIs) in this driving subsector classification are not too poorly ranked $\left(2^{\text {nd }}, 4^{\text {th }}, 5^{\text {th }}, 6^{\text {th }}, 10^{\text {th }}\right.$ and $\left.11^{\text {th }}\right)$. Thus, according to our results, the government has to prioritize its investments in the following branches: Grain Processing and Starchy Product Manufacturing (GPSPM), Cocoa \& Coffee Processing (CCP), Oilseed Industry (OI), Dairy Industry and Fruit \& Vegetable Industry (DIFVI), Beverage Industry (BI), Tobacco Industry (TI). For the Dairy Industry and Fruit \& Vegetable Industry (DIFVI) subsector ranked $6^{\text {th }}$, the post-harvest losses range from 40 to $70 \%$, 
and women are mainly involved in the raw material production sector. The development of this branch would make it possible to revive the economy of the food agriculture subsector, which supports more than $52 \%$ of the population (INSTITUT NATIONALE DE LA STATISTIQUE, 2020).

In addition, the most interesting option for the agro-food industries to become a driving sector is to conquer the domestic and sub-regional market, not only because of proximity but also similarities in food preferences, which is a source of competitive advantage. In addition, the rate at which the African population is growing, combined with the urbanization and densification of territories, is an opportunity for the development of AFIs. However, these products should be low-cost and nutritionally adapted to people's needs. Also, industries producing most of their output for the large population are more resilient to external shocks.

The risk for an agro-food marketing strategy targeting domestic market is the low purchasing power of the population. The strategy of orienting products towards domestic and West African markets should be accompanied by a policy to enlarge the African middle class capable of consuming the products offered by industrialists. This strategy could be helped by a policy of savings, domestic investment by nationals, and an adequate fiscal policy, as recommended by the WORLD BANK (2019).

\section{Analysis of the low ability of AFI to become a driving} sector

Agro-Food Industries are also very insensitive compared to other subsectors of the economy. Innovations are low in this sector, due to obsolete technologies used. They are even less sensitive than agricultural sector's subsectors such as Food Agriculture (FA), Industrial \& Export Agriculture (IEA). AFIs are characterized by their being a little more of stimulating than sensitive industries. All AFI subsectors have lower than average ripple effects $0.132 \%$. This low power and sensitivity for AFI resulted from the low integration of branches among themselves and with the agricultural sector, especially the Food Agriculture subsector, and from the obsolete technologies used. These results are in line with those of KOKO (2013). Today, food processing initiative is no longer the responsibility of the Government. It lies with the private sector, whose primary motivations are profit and business opportunities. Local processing activities are conducted at three different levels: Artisanal, Semiindustrial, and Industrial. Artisanal processing mainly concerns food products, in this case, very highly consumed products such as starchy foods, cereals and market garden produce. The processing rate for these food crops remains very low (less than 5\%), except for rice, with nearly all the paddy rice produced being processed by small units into milled rice. The technologies and processes used to process these products remain rather rudimentary, due to lack of research and capitalization. This illustrated the weak integration between the agricultural sector and the AFI sector (NOUFOU et al, 2019). Semi-industrial processing is supported by the National Centre for Agronomic Research (CNRA) and by the Centre for Demonstration and Promotion of Technologies (CDT). Technologies reported are poorly disseminated. These findings further illustrate poor integration of AFI with research. Industrial processing is essentially done by multinationals and involves a very small number of crops (coffee, cocoa, palm, sugar, cotton, rubber and cashew nuts). It is also focused on $1^{\text {st }}$ and $2^{\text {nd }}$-stage processing, meaning that the branches of the sector are less integrated among themselves and with the rest of the economy. These industries are; therefore, not industrialising ones, i.e. they do not lead to creation of other industries.

Also, access to financing for Small and Medium Industries (SMIs) is limited, especially for the acquisition of modern equipment and the working capital for operations. Poor access to financing for SMIs leads to undercapitalized and under-equipped SMIs. This reduces the country's productivity and competitiveness over competing countries. Technological capital is insufficient due to the under capacity of applied research compared to emerging countries in Africa and Asia. Finally, existing technologies are limited relative to the number of products to be processed, which is why very few locally available raw materials are processed. The production capacity of the Agro-Food Industries is reduced to a specific number of products to be processed (oil palm, cotton, sugar cane, cashew nuts, etc.). The size of companies does not allow for economies of scale. All of these constraints can explain why the AgroFood Industry is not the driving sector of the Ivorian economy, according to our results.

Challenges to the Agro-Food Industry are similar in sub-Saharan Africa, according to KINGSLEY \& AISSATA, (2014). The processing rate for food crops remains very low. Nowadays, only South Africa has an Agro-Food Industry and trade skills. According to DIALLO (2017), the constraints to the development of this sector can be explained by lack of human capacities and skills. African industries 
(Ghana, Senegal, Zambia, Nigeria etc.) do not have sufficient experience in terms of management and development of companies operating in the agrofood sector, not forgetting the crucial issue of research funding, and the AFI sector. All of these prevent AFI from becoming the driving branch/sector of African economies. Furthermore, according to the World Bank, AFI is crucial for Africa "as it is necessary for world food security".

The problems of AFI are presented differently in developed countries. According to RASTOIN (2012), most big agro-food companies use stock market, where hedge funds are active, to finance themselves. These financings require high returns in the short term and have amplifying effects on price volatility. Such factors cause enormous problems for farmers and the AFI, especially small businesses. This forces firms to use sophisticated production systems and marketing technologies and to intensively harness biological resources, leading to further major challenges: control of greenhouse gas emissions, control of waste production and soil pollution, improved energy efficiency (bioenergy production) or biodiversity conservation, climate change, use of bio-recyclable raw materials, control of food waste, improving nutritional quality, food biosecurity and certification, improving information on manufacturing conditions and consumer confidence in such information, as well as digitization of information for traceability, and development of E-commerce (barcode, QR code, Blockchain technology). All this shows the divergent nature of AFI problems for developed and underdeveloped countries.

\section{CONCLUSION}

The upstream and downstream ripple effects of Agro-Food Industry's branches, assessed by the Leontief method, showing that the most powerful branches are not the most sensitive. When value added (VA) is used as an adjustment parameter (Diamond method), it appears that the upstream and downstream ripple effects are weaker, and the powerful or sensitive branches are no longer so. These results reflect the fact that the branches of the economy produce less value added, resulting in poor performing of the national economy.

According to Rasmussen method, there is no driving branch in Agro-Food Industry sector (that is more powerful and sensitive, with a homogeneous degree of impact on other branches) in the Ivorian economy. However, some branches are close to compliance with driving branch status. These are in order: Grain Processing and Starchy Product Manufacturing (GPSPM), Cocoa \& Coffee Processing (CCP), Oilseed Industry (OI), Dairy Industry and Fruit \& Vegetable Industry (DIFVI), Beverage Industry (BI), Tobacco Industry (TI). So, the investments must be oriented in order of this prioritization, with a view of improving the national economy efficiency. To improve the lead of Agro-Food Industry in becoming the economy's driving sector, the government should raise industrial productivity by creating an incentive framework towards the emergence of innovation hubs. The Government must promote entrepreneurship and develop a strategy for businesspeople to access appropriate funding. It must pursue efforts to improve the business environment. Companies should also consider improving and diversifying their technological capital in order to increase food agriculture processing.

The limitation of this study is that it does not consider aspects such as the trade ripple effect (domestic \& international markets and dual trading), the technical efficiency of AFI branches, and the industrializing effects towards effective development of Côte d'Ivoire. All the weaknesses analyzed should foster the development of a sound investment policy, and indirectly a sound economic policy. These limitations could be the subject of other studies.

\section{ACKNOWLEDGMENTS}

We address our special thanks to the General Director of the National Institute of Statistics (INS), to the Ivorian Ministry of Planning and Development, without whom this study could not have taken place.

\section{DECLARATION OF CONFLICT OF INTEREST}

The authors declare no conflict of interest. The founding sponsors had no role in the design of the study; in the collection, analyses, or interpretation of data; in the writing of the manuscript, and in the decision to publish the results.

\section{AUTHORS' CONTRIBUTIONS}

All authors contributed equally for the conception and writing of the manuscript. All authors critically revised the manuscript and approved of the final version.

\section{REFERENCES}

AFRICAN DEVELOPMENT BANK. "Document de stratégie pays (DSP 2018- 2022) combiné avec la revue de la performance du portefeuille pays 2018", Côte d'Ivoire, African Development 
Fund, 2018, 21P. Available from: <https:/www.afdb.org/fr/ documents/document/cote-divoire-country-strategy-paper-csp2018-2022-combined-with-2018-country-portfolio-performancereview-103962>. Accessed: Mar. 10, 2020.

BERNADE C., LECLERCQ C. Industrie Agro-alimentaire Pas-de-Calais. Ouvrage, p.1-33. 2005. Available from: <http://a. bouque.eurotech.free.fr/dp3_prof/dp3_activites/a_decouverte des_metiers/doc/metiers_2015/enjeu\%20nordpasdecalais/03 IAA.pdf $>$. Accessed: Mar. 10, 2020.

DIALLO, B. État des lieux du secteur Agro-alimentaire en Afrique en 2017, Agrobusiness, 2017. Available from: <https://dev. afrikatech.com/fr/agrobusiness/etat-des-lieux-du-secteur-agroalimentaire-en-afrique-en-2017>. Accessed: Mar. 10, 2020.

COCHET, H., DEVIENNE, S. Fonctionnement et performances économiques des systèmes de production agricole: une démarche à l'échelle régionale. Cahiers Agricultures, vol.15, n.6, p.578583, 2006. Available from: <https://www.researchgate.net/ publication/283076797>. Accessed: Mar. 10, 2020.

COURLET C. L'industrialisation du tiers monde: Acquis théorique et modalité d'une remise en cause. Revue tiers-monde tome XXIX, p.24-32, 1988. Available from: <https://www.persee.fr/ doc/tiers_0040-7356_1988_num_29_115_3712>. Accessed: Mar. $10,2020$.

CNUCED. L'entreprenariat au service de la transformation structurelle - Changer de cap, rapport sur les pays les moins avancés, 2018. 214p. Available from: <https://unctad.org/fr/ system/files/official-document/ldcr2018_fr.pdf>. Accessed: Mar. 10,2020

DEBERNISGÉRARDDESTANNE.Industriesindustrialisantes et contenu d'une politique d'intégration régionale en Économie. Appliquée. T. XIX, N. p.3-4, Paris, 1966. Available from : <https:// www.persee.fr/doc/tiers_0040-7356_1971_num_12_47_1802>. Accessed: Mar. 10, 2020

DIAMOND, J. Secteurs clés de l'économie de Singapour. Revue économique malaise, XXI, p74-91. 1976 Available from: $<$ https://scholar.google.com/scholar?hl=fr\&as sdt $=0,5 \&$ as vis $=1 \& q=$ Diamond, $+\mathrm{J} .+1976,+$ secteur $+\mathrm{cl} \% \mathrm{C} 3 \% \mathrm{~A} 9+\mathrm{de}+1 \% 27 \%$ C3\%A9conomie+de+Singapour $>$. Accessed: Mar. 10, 2020.

DUCROQUET, H. et al. L'agriculture de la Côte d'Ivoire à la loupe: Etat des lieux des filières de production végétales et animales et revue des politiques agricoles, p.17-96, 2017. Available from: $<$ https://hal.inrae.fr/hal-02790380>. Accessed: Mar. 10, 2020.

GAULT F., ZHANG G. The role of innovation in the area of development. In: Kraemer-Mbula E and Wamae W, eds. Innovation and the Development Agenda". OECD/IDRC. Paris, p.14-17, 2010. Available from: <https://www.researchgate.net/publication/289901609 The_Role_of_Innovation_in the_Area_of_Development $>$. Accessed: Mar. 10, 2020. doi: 10.1787 / $9789264088924-4-f r$.

HIRSCHMAN A. O. The Political Economy of ImportSubstituting Industrialization in Latin America, The Quarterly Journal of Economics, vol.82, n.1 , p.1-32, 1968. Available from: $<$ https://academic.oup.com/qje/article-abstract/82/1/1/1849281?redirect edFrom=fulltext $>$. Accessed: Mar. 10, 2020. doi: 10.2307/1882243.

INSTITUT NATIONALE DE LA STATISTIQUES. Classification ivoirienne des activités et des produits. Ministère du Plan et du Développement, Côte d'Ivoire, 2020. Available from: <http:// www.ins.ci/n/>. Accessed: Jun. 19, 2020.

KARANGWA J., DECALUWE B. Liaisons, effets d'entraînement et stratégie de développement économique: une application au Rwanda, Département d'économique, Université Laval, Québec, article, Revue canadienne d'études du développement, p.241258, 1983. Available fom: $<$ https://doi.org/10.1080/02255189.198 3.9670064>. Accessed: Mar. 10, 2020.

KINGSLEY I., AISSATA H. L'Agroalimentaire en Afrique: mythe ou réalité?", Édition Spéciale Agriculture, 2014, 8p. Available from: <https://www.un.org/africarenewal/fr/ magazine $/ \% \mathrm{C} 3 \% \mathrm{~A} 9$ dition-sp $\% \mathrm{C} 3 \%$ A 9 ciale-agriculture$2014 / 1 \%$ E2\%80\%99agroalimentaire-en-afrique-mythe-our\%C3\%A9alit\%C3\%A9>. Accessed: Mar. 10, 2020.

KOKO, K. B. Le rôle des Industries Agro-alimentaires dans la croissance agricole : Cas de la Côte d'Ivoire». U. I. Z. Mémoire: Doctorat en Sciences Economiques, p.10-97., 2013. Avalaible from: <http://thesesenafrique.imist.ma/handle/123456789/1424>. Accessed: Mar. 10, 2020.

LEONTIEF, W. W. Quantitative input and output relations in the economic systems of the United States" Review of Economics and Statistics, vol.18, n.3, p.105-125, 1936. Available from: <https:// books.openedition.org/enseditions/11407?lang=fr $>$. Accessed: Mar. 10, 2020.

LEONTIEF, W. W. Dynamic analysis, p.53-90, 1953. Avalaible from: <https://books.openedition.org/enseditions/11407?lang=fr >. Accessed: Mar. 10, 2020.

MINISTRY OF INDUSTRY AND MINES. La conjoncture industrielle à fin 2017, bulletin d'information industrielle, n. 50 , 2017. 5 p.

MYRDAL, G. Théorie économique et pays sous-développés. Présence africaine, p.6-9, 1959. Available from: $<$ https://www. monde-diplomatique.fr/1960/02/A/23461>. Accessed: Mar. 10,2020 .

NOUFOU C. et al. Analysis of the Commercial Integration Between Agricultural and Agro-Food Industries Sectors in Côte d'Ivoire, International Journal of Agricultural Economics, vol.4, n.4, 2019, p.144-153. Available from: $<$ http://www.sciencepublishinggroup. com/journal/paperinfo?journalid $=232 \& \mathrm{do} i=10.11648 / \mathrm{j}$. ijae.20190404.12>. Accessed: Jun. 13, 2019. doi: 10.11648/j. ijae.20190404.12

NOUFOU C., GERARD G. Stratégie de développement de l'industrie agro-alimentaire en Côte d'Ivoire». Série Conférences $N^{\circ} 34$, Centre Sahel-Département d'Economie Rurale de l'Université Laval, Québec-Canada, 1993, 24p. Available from: $<$ http://enda-cremed.org/bpd/opac css/index.php?lvl=author see\&id=9988>. Accessed: Mar. 10, 2020.

PERROUX, F. L'effet d'entraînement: l'analyse au repérage quantitatif, Économie appliquée». n.2, p.2-11. 1973.

RASMUSSEN, N. P. Etudes sur les relations intersectorielles Amsterdam, Kobenhawn: Eimar Harcks Forlag \& North-Holland Publishing Company. 1956, 214p. Avalaible from: <https://books.google.ci/books/about/Studies_in_Inter sectoral_Relations_by_N.html?id=RGfNQwAACAAJ\&redir esc $=\mathrm{y}>$. Accessed: Mar. 10, 2020. 
RASTOIN, J. L. Le système alimentaire mondial: Concepts et méthodes, analyses et dynamiques. Paris-Versailles, Éditions Quæ, 2012. 565p. Available from: <https://doi.org/10.4000/ economierurale.3444>. Accessed: Mar. 10, 2020.

SHEN J, et al. Challenges facing U.S. Manufacturing and Strategies. Journal of industrial technology. 2007, 10p. Available from: $\quad<$ https://www.researchgate.net/publication/328774005 Challenges_and_Status_on_Design_and_Computation_for Emerging_Additive_Manufacturing_Technologies $>$. Accessed: Mar. 10, 2020.

WORLD BANK. Ninth report on the economic situation in Côte d'Ivoire, p.7-76, 2019. Avalaible from: <https:// www.worldbank.org/en/country/cotedivoire/publication/ cote-divoire-economic-outlook-why-the-time-has-come-to- produce-cocoa-in-a-responsible-manner>. Accessed: Mar. $10,2020$.

YU, Y., et al. Construction and application of Regional InputOutput Models: Assessing Water Consumption in South East and North East of England. Ecological Economics, vol.69, p.1140-1147, 2010. Available from: <https:/geog.umd.edu/ publicationprofile/646>. Accessed: Mar. 10, 2020.

ZAOUJAL, N. Contribution De La Consommation Finale Des Ménages A La Croissance Et A La Création D'emploi Au Maroc: Simulation A L'aide D'un Modèle Input-Output. Global Journal of Management and Business Research: B Economics and Commerce, vol.16, n.7, 2016. Available from: <https:// globaljournals.org/GJMBR_Volume16/5-Contribution-De-LaConsommation.pdf>. Accessed: Mar. 10, 2020. 